ECONOMICS

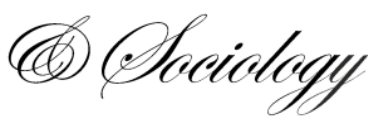

\title{
HOW EFFECTIVE IS INSTITUTIONAL QUALITY FOR THE CREATION OF SMALL \& MEDIUM ENTERPRISES (SMES) IN INDONESIA?
}

\author{
Kumba Digdowiseiso \\ University of National, \\ Jakarta, Indonesia \\ E-mail: \\ kumba.digdo@,civitas.unas.ac.id \\ ORCID 0000-0003-0848-8541 \\ Eko Sugiyanto \\ University of National, \\ Jakarta, Indonesia \\ E-mail:ekoantodr@gmail.com \\ ORCID 0000-0001-9525-238X
}

Received: April, 2020

1st Revision: December, 2020

Accepted: February, 2021

DOI: $10.14254 / 2071-$

789X.2021/14-1/17

JEL Classification: $\mathrm{O} 11$, $\mathrm{O} 17, \mathrm{O} 43$
Digdowiseiso, K., \& Sugiyanto, E. (2021). How effective is institutional quality for the creation of small \& medium enterprises (SMEs) in Indonesia?. Economics and Sociology, 14(1), 263-274. doi:10.14254/2071-789X.2021/14-1/17

\begin{abstract}
A good business environment can enhance the growth of small and medium enterprises (SMEs) that leads to better economic growth and development. Many developing countries, including Indonesia, have conducted several business reforms to support this mission. Our research aims to investigate the effect of institutional quality on the formation of SMEs in Indonesia. Additionally, our study will examine how implementation of regulations and policies by the local governments influence the creation of new SMEs in Indonesia. We use a sequential explanatory strategy whereby quantitative data collection and analysis is followed by the qualitative ones. The results of negative binomial regressions over the period of 2009-2018 show that the incidence of corruption, as well as law and order, have a positive effect on the number of new SMEs in 32 provinces of Indonesia. Meanwhile, qualitative analysis confirms the findings from the quantitative analysis that there are some problems related to the governance of licensing process such as the economic rent-seeking practices, weak coordination among local government units, the absence of a periodic evaluation, the incapability of local government apparatus in mastering information technology (IT), and the culture of gratification.
\end{abstract}

Keywords: institutional quality, corruption, law and order, SMEs, Indonesia.

\section{Introduction}

In a recent World Bank's publication Doing Business 2020: Comparing Business Regulation in 190 Economies, Indonesia's position by the Ease of Doing Business (EoDB) remained the same, the $73^{\text {rd }}$ out of 190 countries surveyed. The country is still lagging behind other South-East Asian countries, such as Singapore, Malaysia, Thailand, and Vietnam. Of the ten criteria in evaluating business climate, the indicators of starting a business, the ease of obtaining construction permits, credit, and electricity, as well as the protection of minority investors in Indonesia showed a sign of improvement. However, the Government of Indonesia (GoI) should focus their attention on improving the land and building certification issues as well as tax payments. 
Small and medium enterprises (SMEs) are the largest business sector in Indonesia and account for the largest proportion of employment. However, the majority of firms in Indonesia are informal SMEs, operating in the food \& beverage industry and in the services sector (Digdowiseiso, 2012). These companies often do not have access to the financial sector, thus, they are unable to sell their products to large buyers and/or carry out export activities. Since the registration fee is relatively high in Indonesia, such a precondition can deter firms in the informal sector from formalizing their business. The same report showed that the cost of starting a business in Indonesia reached about $11 \%$ of the income per capita (USD 1,443). This is a relatively high number if compared with other countries such as Singapore, Thailand, and Vietnam who are spending USD 468, USD 1,161 and USD 480, respectively.

The inefficiencies in the licensing framework create significant obstacles for many investors. In this context, Lewis and Sjahrir (2009) stated that in terms of processing time and procedures compliance costs were considered to be more important than the monetary costs. Additionally, the 2020 Doing Business report indicated that potential investors in Indonesia required 11 procedures and 23 working days to start a business. In contrast, in Singapore, Thailand, Malaysia, and Vietnam they would need 3 procedures and 3 days, 5 procedures and 5 days, 9 procedures and 19 days, as well as 9 procedures and 22 days respectively.

Duration of these procedures opens up an opportunity for bribery in a bid to cut the red tape. In this context, Kuncoro (2004) found that bribery was positively related to firm licensing in Indonesia. The lack of transparency and clarity in the processing of licenses spurred many businessmen to pay more to speed up the licensing process. On a broader scope, the research conducted by (Digdowiseiso, 2018) showed that bribery practices in developing countries could inhibit the rate of economic growth. This was caused by the continuous emergence of additional costs incurred by the company so that company's profits in the short term and job creation in the long run are both hindered.

The entry barriers (lengthy procedures as well as high costs of starting a business) can determine growth by hampering the creation of new firms, including SMEs (Klapper \& Love, 2011). Our study will focus on new rather than old businesses because their size and magnitude of labor participation and growth rates are much bigger and more robust (Haltiwanger et al., 2013). Moreover, Jayasuriya (2010) points out that there is a discrepancy between the actual business implementation and its expectation as stated in the current law and order. As the creation of SMEs involves the institutional quality of all stakeholders, particularly those related to the implementation of policies and regulations at the sub-national level and those responsible for reducing the entry barriers, it is essential to further inspect how the quality of institution affects the formation of new SMEs in Indonesia. In this context, we set 32 provinces of Indonesia as the objects of quantitative analysis. Our time frame of analysis covers the period of 2009-2018, since the Government of Indonesia nationalized the One-Stop Services (OSS) concept in 2007 but its implementation started effectively in 2008. Therefore, our study can be viewed as an evaluation of a business licensing institution.

To complement the quantitative findings, we have also conducted several observations and semi-structured interviews (SSIs) in three locations of the Integrated One-Stop Service (Pelayanan Terpadu Satu Pintu-PTSP). In principle, Indonesian government has implemented such licensing reforms for almost 12 years through the MoHA (Ministry of Home Affairs, Kementerian Dalam Negeri) ordinance No. 138/2017 on the Implementation of the Integrated One-Stop Services at Regional Level, which refers to the Government Regulation No. 96/2012 concerning the Implementation of the Law No. 25/2009 on Public Services. Although local and provincial governments have formed PTSPs, the number of PTSPs that had the Minimum Service Standard (Standar Pelayanan Minimal - SPM) and delegated the licensing authority to PTSP only reached 405 and 200 regions out of 532 regions respectively (MoHA, 2019). 
Therefore, better understanding of the PTSPs governance in assisting entrepreneurs to formalize their business is very important to investigate.

The next section discusses the literature review. It is followed by the justification of data and empirical methodology. The empirical results describe the outcomes from the examination of institutional quality on SMEs creation in 32 provinces over the period of 2009-2018. Meanwhile, qualitative findings will be elaborated in the discussions.Finally, we also provide conclusions and policy recommendations.

\section{Literature review}

The empirical researches whether in the form a cross-country or a single country analysis that investigate the effect of institutional quality on the formation of SMEs are relatively scant. Most of the literature put their attention on the institutional quality - economics development nexus. For example, both Acemoglu et al. (2001) and Rodrik et al. (2004) showed that there was a significant and positive correlation between institutional quality and Gross Domestic Product (GDP) per capita in the former European colonies. Similarly, Barro (2003) explained that rule of law was positively and significantly associated with growth. Meanwhile, Aghion (2004) proved that a better institutional environment stimulated entrepreneurship, which led to an increase in the growth of the economy. In another study, Dixit (2009) shed some lights on the major role of institutional quality that contributed to an efficient market. It took place when a country implemented a better level in securing property rights, contract enforcement, and collective action.

Some empirical cross-country studies focus on how the business environment affects firm creation in general. For instance, Fonseca et al. (2001) showed that costs in starting a business were negatively and significantly associated with the number of potential investors and the formation of new firms. Meanwhile, van Stel et al. (2007) indicated that a minimum capital in starting a business and labor regulations was negatively and significantly correlated with firm creation in 39 countries. However, the administrative costs related to the procedures and duration in starting a business appeared to be insignificant in the models. Unlike van Stel's et al. results, Klapper and Love (2011) found that the duration and procedures were negatively and significantly correlated with the number of new firms. They also highlighted that firm creation and the growth of the economy would grow faster if countries adopted the licensing reforms.

To some extent, our study is closely related to Canare's (2018) research. In this context, he investigated the effect of ease of doing business on firm creation in 120 countries over the period 2004 - 2012. By using the System Generalized Method of Moments (GMM), he found that governance was positively and significantly correlated with the business density. However, there are two weaknesses, as follows: First, governance can only explain some proportions of the output and or outcome dimension of institutional quality at the national level as it contains other aspects such as rule of law, corruption, and bureaucratic quality (Rothstein \& Teorell, 2008). Last, the micrometric of institutional quality which is related to social capital at the community level is neglected in his study (Grootaert \& van Bastelaer, 2002).

Two studies are indirectly associated with our investigation in Indonesia. First, Kuncoro (2006) examined rent-seeking behavior in business licensing process. He found that a firm would engage in lobby and negotiation if the red-tape was sufficiently high, and if the marginal effectiveness of bribes outweighed the marginal cost of bribes after taking uncertainty into consideration. Last, Rothenberg et al. (2016) shed some lights on the persistence and scale of informal sector in Indonesia. They discovered that the OSS had no effect on firms' informality 
rates. Based on previous empirical results, in this paper, we hypothesize that institutional quality has a positive and significant effect on business density.

\section{Methodology}

This research uses a sequential explanatory strategy, which is characterized by the collection and analysis of quantitative data in the first phase of research It is followed by the collection and analysis of qualitative data in a second phase that is built on the results of the quantitative analysis (Creswell, 2013). On the quantitative method, our dependent variable of new SMEs is treated as an event in the form of count data. Hence, it cannot be treated as a continuous random variable (Cameron \& Trivedi, 2005).

A popular analysis for count data is a Poisson regression (Cameron \& Trivedi, 2005). However, there is evidence of over dispersion in the SMEs data in which the variance is greater than the mean. Therefore, a negative binomial regression can be viewed by several scholars as an alternative (see Murshed \& Tadjoeddin, 2008; Sugiyanto et al., 2018a). A preliminary analysis showed that over dispersion existed and hence, we use a negative binomial in a panel model (see Figure 1).

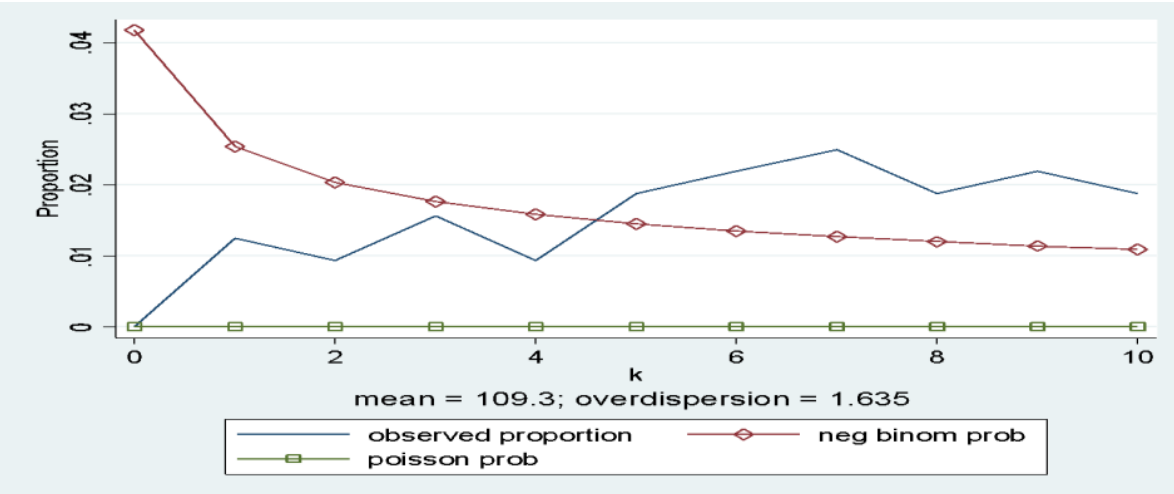

Figure 1. Over dispersion in SMEs Density

Source: Authors' contribution, 2019

The following benchmark of a baseline negative binomial model at a cross-province level will be used:

$$
\mathrm{SME}_{\mathrm{it}}=\beta_{0}+\beta_{1} \mathrm{Ins}_{\mathrm{it}}+\mathrm{u}_{\mathrm{i}}+\mathrm{v}_{\mathrm{t}}+\varepsilon_{\mathrm{it}}
$$

where $\beta_{0}$ denotes the constant term, the subscript $\mathrm{i}$ constitutes 32 provinces, $\mathrm{t}$ corresponds to the observation period 2009-2018, and $\varepsilon_{i t}$ is the corresponding disturbance term. We incorporate the year Fixed Effects $(\mathrm{FE}), \mathrm{v}_{\mathrm{t}}$, to control the time-variant unobserved characteristics. In contrast, the province $\mathrm{FE}, \mathrm{u}_{\mathrm{i}}$, can manage the time-invariant characteristics within the specific province. In this case, we utilize dummy for development since GoI still put a lot of resources (e.g. human and financial) to develop the sub-national governments within the island of Java, before and after the period of the 2001 decentralization. The annual record of SMEs is based on the National Socio-Economic Survey (Survei Sosial Ekonomi Nasional SUSENAS) at an inter-regional level in Indonesia, which is compiled by the national statistical agency (Badan Pusat Statistik - BPS). In this context, we can provide the number of new SMEs registered in the province per 1,000 individuals aged 15 to 64 that denotes to the 'SMEs density' à la Canare (2018). 
The main interest throughout this article lies in the coefficient $\beta_{1}$, which measures the effect of institutional quality on the number of new SMEs. Following Canare's investigation, we expect that the quality of an institution is positively and significantly correlated with SMEs density. Rothstein and Teorell (2008) show that it can be best described in terms of input and output. The former is related to the access to a public authority (e.g. democracy), while the latter corresponds to how authority is exercised (e.g. government quality of governance). In another perspective, Grootaert and van Bastelaer (2002) show that it can be measured at the macro and micro level. The former is associated with the rule of law, bureaucratic quality, and corruption at the national and government level, while the latter constitutes social capital, trust, network, and collective action at the community level.

In this study, we use all inter-regional measures of institutional quality, as follows: First, we use indices of democracy that are a composite index from civil freedom, political rights, and democratic institution, which constitutes zero (0) as regions belong to the authoritarian regime and one hundred (100) as regions have full experience in democracy. Data on democracy are obtained from BPS and are available from 2009 to 2018. Second, we obtain crime rates as a proxy indicator for law and order since they reflect the quality and capacity of law enforcement in preventing and punishing criminals (Sugiyanto et al., 2018a). Data on crime rates are related to the number of crime scenes at province level and are compiled by BPS every year from 2009 to 2018. Third, we utilize the incidence of corruption at cross-province level based on the Corruption Eradication Commission (Komisi Pemberantasan Korupsi - KPK) dataset that is available from 2009 to 2018.

Fourth, to gauge the quality of bureaucracy, we construct indices of service delivery that correspond to the outcome performance of the sub-national governments on general public services, which can be analyzed in terms of education (i.e. average years of schooling), health (i.e. water and sanitation), and infrastructure (i.e. road condition) sector at cross-province level. Such dataset denotes zero (0) if regions have the lowest bureaucratic quality and five (5) if regions have the highest quality. These outcome variables are provided by BPS from 2009 to 2018. Last, we deploy indices of social capital which refer to a composite index from trust and tolerance, participation in groups and networks, as well as reciprocity and collective action. It constitutes zero (0) as regions have no social capital at all and one hundred (100) as regions have a full abundance of social capital. Such data are obtained from BPS and are available in 2009, 2012, 2014, and 2017.

Table 1 provides statistics summary on the estimation of SMEs density in Indonesia. Averagely, the number of new SMEs in Indonesia is relatively moderate, however the indicator of corruption is very low. Moreover, the average of bureaucratic quality of each province in Indonesia is still relatively moderate, despite having a modest level of democracy as well as law and order, as well as a low level of social capital.

Table 1. Summary of statistics

\begin{tabular}{lccccc}
\hline \multicolumn{1}{c}{ Variable } & Observation & Mean & Std. Deviation & Min & Max \\
\hline SMEs density & 320 & 109.34 & 210.93 & 1 & 1204 \\
\hline Democracy & 320 & 69.16 & 6.53 & 52.61 & 85.58 \\
\hline Social Capital & 128 & 52.96 & 6.49 & 38 & 63.16 \\
\hline Corruption & 320 & 0.17 & 0.56 & 0 & 5 \\
\hline Law \& Order & 320 & 185.73 & 95.02 & 14 & 557 \\
\hline Bureaucratic Quality & 320 & 3.11 & 0.53 & 2 & 4 \\
\hline
\end{tabular}

Source: Authors' contribution, 2019

The above econometric results are followed by fieldwork analysis in three (3) objects of analysis, namely: (1). Regency of Sragen at Central Java province; (2). City of Padang at 
West Sumatra province; and (3). Regency of Manggarai at East Nusa Tenggara province. The selection of these regions is based on the characteristics of PTSP which denote 'developed' as PTSP had SPM and the local government already delegated licensing authority in PTSP, 'developing' as PTSP had SPM but PTSP had no authority in licensing, and 'least developed' as PTSP had no SPM and authority in licensing. The collection of data in these regions was carried out through the adoption of semi-structured interviews (SSIs) from July 2019 to November 2019 that involves Head of PTSPs, Head of Local Development and Planning Agency (Badan Perencanaan Pembangunan Daerah - Bappeda), Academicians, SMEs businessmen, and Local Business Associations.

\section{Empirical results}

In this paper, we want to investigate the effect of institutional quality, gauged by social capital, democracy, incidence of corruption, law and order, as well as bureaucratic quality, on SMEs creation, measured by SMEs density. Based on estimation in the period 2009-2018, we have $128-320$ observations that spread in 32 provinces. We started to analyze the institutional quality - SMEs density nexus with the basic panel of random effects (RE) and fixed effects (FE) estimations with the standard of the error-corrected method. Such a method can tackle the heteroscedastic issue. We also took into account the issue of cross-sectional dependence in all models due to spatial effects and unobserved common factors (Baltagi \& Pesaran, 2007). Hence, in RE models, we only estimated year FE, while in FE models, both year and state FE were utilized.

Overall, democracy and bureaucratic quality were negatively and significantly associated with SMEs density (see Table 2).

Table 2. Negative Binomial Panel Regressions on SMEs Density ${ }^{1}$

\begin{tabular}{|c|c|c|c|c|c|c|c|c|c|c|}
\hline \multirow{3}{*}{$\begin{array}{c}\text { Exp. } \\
\text { Variables }\end{array}$} & \multicolumn{10}{|c|}{ Dep. Variable: SMEs Density } \\
\hline & $\mathbf{R E}$ & FE & $\mathbf{R E}$ & FE & $\mathbf{R E}$ & FE & $\mathbf{R E}$ & FE & $\mathbf{R E}$ & FE \\
\hline & (1) & (2) & (3) & (4) & (5) & (6) & (7) & (8) & (9) & (10) \\
\hline Democracy & $\begin{array}{c}-0.01 * * * \\
(0.003)\end{array}$ & $\begin{array}{l}-0.003 \\
(0.004)\end{array}$ & & & & & & & & \\
\hline Soc. Capital & & & $\begin{array}{c}0.01 * * * \\
(0.005)\end{array}$ & $\begin{array}{c}0.01 \\
(0.02)\end{array}$ & & & & & & \\
\hline Corruption & & & & & $\begin{array}{c}0.05 * * * \\
(0.02)\end{array}$ & $\begin{array}{c}0.13 * * * \\
(0.03)\end{array}$ & & & & \\
\hline $\begin{array}{ll}\text { Law } & \& \\
\text { Order } & \end{array}$ & & & & & & & $\begin{array}{c}9 \mathrm{e}^{-4 * * * *} \\
\left(3 \mathrm{e}^{-4}\right)\end{array}$ & $\begin{array}{l}6 \mathrm{e}^{-4 * *} \\
\left(3 \mathrm{e}^{-4}\right)\end{array}$ & & \\
\hline Bur. Quality & & & & & & & & & $\begin{array}{c}-0.20 * * * \\
(0.06)\end{array}$ & $\begin{array}{l}-0.03 \\
(0.06)\end{array}$ \\
\hline Year Effect & No & Yes & No & Yes & No & Yes & No & Yes & No & Yes \\
\hline State Effect & Yes & Yes & Yes & Yes & Yes & Yes & Yes & Yes & Yes & Yes \\
\hline Observation & 320 & 320 & 128 & 128 & 320 & 320 & 320 & 320 & 320 & 320 \\
\hline Group & 32 & 32 & 32 & 32 & 32 & 32 & 32 & 32 & 32 & 32 \\
\hline Log & -1345.63 & -1072.18 & -580.55 & -355.03 & -1350.32 & $2-1064.71$ & -1348.25 & -1070.62 & -1346.97 & -1072.36 \\
\hline $\mathrm{X}^{2}(\mathrm{p}$-value $)$ & 0.00 & 0.00 & 0.00 & 0.00 & 0.00 & 0.00 & 0.00 & 0.00 & 0.00 & 0.00 \\
\hline
\end{tabular}

Source: Authors' contribution, 2019

\footnotetext{
${ }^{1}$ Number of parentheses are robust standard error. Asterisks denote: $* * *=$ significant at $1 \%$ level; $* *=$ significant at $5 \%$ level; * = significant at 10\% level. Hausman tests suggest that FE models are far superior than RE models. Full results are available upon request.
} 
However, such results were valid in RE models. Similarly, there was a positive and significant association between social capital and SMEs creation in Indonesia. Meanwhile, we found that the incidence of corruption, as well as law and order, were positively and significantly correlated with the number of new SMEs in Indonesia. Such findings were robust whether in RE or FE models. On corruption results, our study appears to be consistent with Kuncoro's (2004) investigation on the relationship between bribery and licensing of firm creation in Indonesia. With regards to the equation of law and order, our finding seems to corroborate Klapper and Love's (2011) study in which regulation is negatively associated formation of the firm. Since our quantitative results cannot elaborate the governance of licensing services at local level, the qualitative method will be utilized to enrich the findings.

\section{Discussions}

In general, there are four principles for assessing the feasibility of taxation at the regional level, such as the adequacy of results, economic efficiency, fairness, implementation capacity, and regulatory compatibility as a source of regional income (Devas et al., 1989) Concerning the fiscal capacity of local governments, tax revenues can arise from various sources, including tax revenue sharing with the central government, taxes levied by the local government itself, and the additional taxes collected from the central government taxes. Ironically, the policy in taxation has increased the creativity of sub-national governments in designing other kinds of taxes and new levies in an attempt to avoid the limits of existing taxes and to increase their own-source revenue (Pendapatan Asli Daerah - PAD).

The 2016 Economics Governance survey conducted by the Committee for Implementation and Monitoring of Regional Autonomy (Komite Pemantauan dan Pelaksanaan Otonomi Daerah - KPPOD, 2016) confirmed levies that had a significant impact to cause the high economic costs and uncertainty in the investment climate, which included the improper and different structures of tariff, the multiple levies along with the central and provincial levies, and even levies that overlapped with other similar levies imposed by a local government, has existed in some sub-national governments for almost 15 years. For example, Ministry of Trade Ordinance No. 7/2017 on the Issuance of Trading Business Permits (Surat Izin Usaha Perusahaan - SIUP) clearly exempts the company from the administrative costs of making a new SIUP. The same case applies to the new TDP (Tanda Daftar Perusahaan - Company Registration Certificate) through Ministry of Trade Ordinance No. 76/2018 on Organizing Company Registration. In practice, none of the entrepreneurs in Manggarai and Padang obtained new TDP and SIUP for free.

In this context, we believe that decentralization, which is actually an instrument to bring public goods and services closer to the community, is interpreted incorrectly. It should allow the licensing procedures to be easy and inexpensive, but in a reality, they become increasingly difficult and expensive. The problems of decentralization that generally occur in Indonesia, among others, are closely related to the delegation of authority and the readiness for implementation. In many cases, the authority shared at various levels of government has not been followed up with the efficient and effective in implementation. Various studies showed that the local government apparatuses were not ready to carry out this authority (Digdowiseiso et al., 2018; Sugiyanto et al., 2018b). Such a situation is closely related to the competencies and capabilities, particularly those who have exposure in licensing process of new SMEs. Overall, there are four (4) problems associated with these matters, as follows:

First, the licensing process requires the knowledge not only limited to the legal aspects of the permit process but also must consider the social and economic impacts that will arise from the issuance of permits. A government apparatus who can estimate such effects should 
possess extensive knowledge in terms of conceptual and technical matters. In our cases at Padang and Manggarai, it is very common to find an executive apparatus that does not have the requirements as intended. This is compounded by the recruitment policies of PTSP employee that are not based on meritocracy.

Second, the use of information technology (IT) can be considered as a means of expediting the licensing process. Thus, public officials are required to operate the computerized system. Unfortunately, some apparatuses in Padang and Manggarai do not have the expertise to operate this system. This kind of official will be a wedge in public service delivery. Therefore, the mismatch between the needs and competencies of the bureaucratic apparatus has led to the low quality in licensing services.

Third, the licensing process cannot be separated from the interaction between the applicant (i.e. entrepreneur) and the licensor (i.e. government apparatus). In such a condition, corrupt behavior might exist whether it is triggered by the business actors or officials. Thus, the mechanism of reward and punishment for PTSP officials is essential to ensure the positive behavior among them. For example, Regency Government of Sragen through the Integrated Service Agency (Badan Pelayanan Terpadu - BPT) implemented an incentive system for its staffs who provided the best service to any potential investors and would impose the administrative sanctions if they violated the provisions as stated in the Standard Operational Procedure (SOP).

Finally, the principles of good governance are required to be applied in licensing services. During our observations in Padang and Manggarai, service officers at PTSP barely had a professionalism attitude and adopted the principle of customer relationship when dealt with potential entrepreneurs. This condition can be avoided if there is a Minimum Service Standard (SPM). However, even if SPM exists as it occurs in Padang, it will only become the formal displays. In this context, the procedure, time, and costs are deliberately created to make entrepreneurs become more dependent on public officials. The SPM also regulates the complaint handling arrangement through the suggestion box. But, the application at the internal and external of PTSP does not work so that investors do not have a strong bargaining power.

The above findings are similar to the results from KPPOD (2011) where they conducted direct interviews with PTSP officials in 130 regions. They revealed several obstacles associated with the position and the form of institutional licensing service. A prominent issue is related to the echelonization of licensing service agencies in Padang and Manggarai where their Local Government Units (Satuan Kerja Perangkat Daerah - SKPD) were unwilling to relinquish some of the licensing authority that was originally theirs to PTSP. Such condition takes place when there is still a sectoral ego from the relevant technical units to maintain the authority of licensing management. Some PTSP officials in Padang and Manggarai also mentioned the structural problems are resulted by a poor commitment on Head of Local Government. Besides, they believed that their Head of PTSP did not have the vision to lead the organization. Therefore, PTSP whose does not possess a leader with a good credibility, high integrity and vision for the long run will have a permissive organizational culture that is not a customeroriented and measures the achievements of organization solely from the income generated by licensing activity.

The mindset of bureaucrats as rulers has made it difficult to change the quality of licensing services. Such a condition has a potential consequence on the obligation of the entrepreneur to pay for more expensive services illegally. These kinds of levies and bribes are the costs of uncertainty that must be incurred every time they deal with bureaucracy. Such a practice has become a culture that is difficult to eradicate.

The front officer of PTSP who is expected to act as an anti-corruption agent never gives clarity about the duration and costs. Instead, they tend to direct customers if they want to 
accelerate the process. Here, the role of the back officer is crucial in negotiating the rates and prices. In principle, this type of abuse of authority can be avoided by the use of technology (i.e. online system) which is viewed as a tool to reduce the direct interactions and hence, corruption. For example, the adoption of the Electronic System for Information Services and Investment Licensing (Sistem Pelayanan Informasi dan Perijinan Investasi secara Elektronik - SPIPISE) in Sragen. However, there are still mechanisms 'outside of the system' that contribute to the cultivation of corruption in PTSP. For instance, some investors in Padang and Manggarai stated that PTSP officials 'took care of' the process of licensing without them submitted the documents in the system.

In terms of investors' perspective, it is not important whether the license is through official or unofficial channels. Instead, they focus on the proof of the transaction. This opportunity is used by brokers in licensing such as the notaries and the private service bureaus to make the licensing packages at a certain price depending on the time the client wants. In other words, these packages are assumed to be valid and more practical for the sake of the firm's accounting system. By contrast, if entrepreneurs used the official channels, they often did not get the payment evidence. This can be found when there were some additional costs outside the stated regulations and or when they provided the bribes to speed up the bureaucratic process.

The difficulties in reducing or even eliminating illegal fees and bribes in licensing services at PTSP are exacerbated by a culture of gratuity and affiliation, as well as a patronclient relationship. Take the example of the process of licensing in Padang and Manggarai where there was a mutual relationship based on political affiliation. In this context, the influential entrepreneurs, who were and still close to the decision-makers in the regions, often received more 'special treatment' than the ordinary businessmen. Other cases are based on the similarity of ethnicity as in Manggarai and religion as in Padang. This is contrary to the essence of Law No. 25/2009 on Public Services where they must be delivered in an effective, efficient, economical, and equal manner.

\section{Conclusion}

Our quantitative results show that incidence of corruption as well as law and order are positively associated with the number of new SMEs in Indonesia. The qualitative findings corroborate the quantitative ones in which there are some problems related to the governance of licensing process in PTSP.

From the perspective of regulation, there are several local regulations that allow levies and fees leading to the economic rent-seeking practices. In this context, the regency and municipal government can utilize these arrangements to attain PAD from licensing activities. Therefore, synchronizing between local regulations and national ones needs to be frequently implemented so that every local government can provide the bureaucratic procedures in obtaining information related to licensing process in an effective and efficient manner.

We also find that the complaints handling mechanisms that ensure the follow-up of complaints/reports on services provided at some PTSPs are not optimal. For this reason, such mechanism needs to be responsive by improving the internal mechanism of complaint handling within PTSP and or by creating a weekly complaint forum. Moreover, the provision of advocacy facilities at the national and local levels needs to be implemented to ensure those who have difficulties in receiving licensing services.

There is also evidence of a weak coordination among institutions because most of PTSPs in our case studies use a hub system. In this context, the heads of SKPD involved in licensing activity still recognize the importance of authority for their own interests, so that they are not willing to delegate their authority to PTSP. Thus, the coordination among licensing providers 
needs to be improved by placing one of authorized officials as a member of back officers in PTSP. Such method implicitly gives a full licensing authority to PTSP.

Another important issue is that the periodic evaluations have not been carried out internally and externally to assess the performance of PTSP. Such problem cannot be separated from the lack of vision and commitment of the Regional Heads. In this context, they only assess PTSP achievements based on licensing revenues. Therefore, the PTSP needs to be monitored and evaluated continuously by either a PTSP Supervisory Board or an independent supervisory agency.

The aspect of governance is also related to the expertise in possessing information technology (IT). Such method is very essential to deliver public goods and services in an accountable, a transparent, and an efficient manner. Therefore, there is an urgency to improve the competency of PTSP officials through capacity building activities continuously. Additionally, the mechanism of reward and punishment for employees is rather vague. Hence, SPM and SOP concerning this matter needs to be formulated and implemented.

On the issue of corrupt behavior, gratification can be based on the habit of the community to give more when they receive services that exceed expectations. In this context, communities still consider 'facilitation payments' as an expression of gratitude and reciprocity for the service. In a worst case scenario, some PTSP officials do not have the power to refuse the 'gift', so that it perpetuates a culture of bribery and gratuity. Corrupt behavior can also be originated from a 'special' affiliation relationship between public officials and customers either due to friendship, kinship, or even political closeness. These problems can actually be avoided if PTSP has a code of conduct that regulates the behavior of its officers. It includes some signs of anti-corruption identity on PTSP employees and offices.

\section{Acknowledgement}

We would like to convey a big gratitude to our fellow lectures at Department of Public Administration and Management, University of National for their valuable comments.

\section{References}

Acemoglu, D., Johnson, S., \& Robinson, J. A. (2001). The Colonial Origins of Comparative Development: An Empirical Investigation. American Economic Review, 91(5), 13691401.

Aghion, P. (2004). Growth and Development: A Schumpeterian Approach. Annals of Economics and Finance, 5(1), 1-25.

Baltagi, B. H., \& Pesaran, M. H. (2007). Heterogeneity and cross section dependence in panel data models: Theory and Applications. Journal of Applied Econometrics, 22(2), 229-32.

Barro, R. (2003). Determinants of economic growth in a panel of countries. Annals of Economics and Finance, 4(2), 231-274.

Cameron, A. C., \& Trivedi, P. K. (2005). Microeconometrics: Methods and Applications. New York: Cambridge University Press.

Canare, T. (2018). The effect of ease of doing business on firm creation. Annals of Economics and Finance, 19(2), 555-584.

Creswell, J. W. (2013). Research design: Qualitative, quantitative, and mixed methods approaches. Thousand Oaks, CA: Sage.

Devas, N., Binder, B., Booth, A., Davey, K., \& Kelly, R. (1989). Keuangan Pemerintah Daerah di Indonesia. Jakarta: Universitas Indonesia Press. 
Digdowiseiso, K. (2012). Notes on economic development: a preliminary finding of global perspectives. Jakarta: Universitas National Press.

Digdowiseiso, K. (2018). Essays on fiscal decentralization: evidence from developing countries with a special focus on Indonesia. PhD Diss., I.S.S. Erasmus University, The Hague.

Digdowiseiso, K., Sugiyanto, E., \& Djumadin, Z. (2018). Implementation of irrigation policy in the decentralized government: a case study of West Java, Indonesia. Journal of Environmental Management and Tourism, 9(3), 411-422.

Dixit, A. (2009). Governance Institutions and Economic Activity. American Economic Review, 99(1), 3-24.

Fonseca, R., Lopez-Garcia, P., \& Pissarides, C. A. (2001). Entrepreneurship, Start-up Costs and Employment. European Economic Review, 45(4-6), 692-705.

Grootaert, C., \& van Bastelaer, T. (2002). Understanding and Measuring Social Capital: A Synthesis of Findings and Recommendations from the Social Capital Initiative. Washington DC: The World Bank.

Haltiwanger, J., Jarmin, R. S., \& Miranda, J. (2013). Who Creates Jobs? Small versus Large versus Young. Review of Economics and Statistics, 95(2), 347-361.

Jayasuriya, D. (2011). Improvements in the World Bank's Ease of Doing Business Rankings: Do they Translate into Greater Foreign Direct Investment Inflows?. Retrieved from https://pdfs.semanticscholar.org/da18/7aa7229f5afc8a7a160d444e5c460c7770c6.pdf

Kementerian Dalam Negeri (Kemendagri). (2019). Buku Pembangunan Daerah Tahun 2019. Jakarta: Kemendagri.

Klapper, L., \& Love, I. (2011). The Impact of Business Environment Reforms on New Firm Registration. Retrieved from http://siteresources.worldbank.org/INTFR/Resources/Klapper_Love_Feb14_12.pdf

Komite Pemantauan Pelaksanaan Otonomi Daerah (KPPOD). 2011. Local Economic Governance. Jakarta: KPPOD.

Komite Pemantauan Pelaksanaan Otonomi Daerah (KPPOD). 2016. Tata Kelola Ekonomi Daerah 2016: Survei Pemeringkatan 32 Ibukota Provinsi di Indonesia. Jakarta: KPPOD.

Kuncoro, A. (2004). Bribery in Indonesia: Some Evidence from Micro-Level Data. Bulletin of Indonesian Economic Studies, 40(3), 329-354.

Kuncoro, A. (2006). Corruption and Business Uncertainty in Indonesia. ASEAN Economic Bulletin, 23(1), 11-30.

Lewis, B. D., \& Sjahrir, B. S. (2009). Local Tax Effect on Business Climate. Retrieved from https://www.researchgate.net/publication/282707289_Local_tax_effects_on_the_busine ss_climate

Murshed, S. M. \& Tadjoeddin, M. Z. (2008). Is Fiscal Decentralization Conflict Abating? Routine Violence and District Level Government in Java, Indonesia. Retrieved from https://papers.ssrn.com/sol3/papers.cfm?abstract_id=1169422

Rodrik, D., Subramanian, A., \& Trebbi, F. (2004). Institutions Rule: The Primacy of Institutions over Geography and Integration in Economic Development. Journal of Economic Growth, 9(2), 131-165.

Rothenberg, A. D, Gaduh, A., Burger, N. E., Chazali, C., Tjandraningsih, I., Radikun, R., Sutera, C., \& Weilant, S. (2016). Rethinking Indonesia's Informal Sector. World Development, 80, 96-113.

Rothstein, B., \& Teorell, J. (2008). What is Quality of Government? A Theory of Impartial Government Institutions. Governance, 21(2), 165-90.

Sugiyanto, E., Digdowiseiso, K., Zulmasyhur, \& Setiawan, H. D. (2018a). Fiscal decentralization and routine conflict in Indonesia. Journal of Applied Economic Sciences, 13(4), 961-969. 
Sugiyanto, E., Digdowiseiso, K., \& Djumadin, Z. (2018b). Irrigation planning in the era of local autonomy: an analysis of existing and alternative model. Journal of Advanced Research in Law and Economics, 9(2), 692-704.

van Stel, A., Storey, D. J., \& Thurik, A. R. (2007). The effect of business regulations on nascent and young business entrepreneurship. Small Business Economics, 28(2-3), 171-186.

World Bank. (2019). Doing Business 2020: Comparing Business Regulation in 190 Economies. Washington DC: World Bank. 